\title{
Operational Solution of Space Monitoring of Grain Crops in South Kazakhstan on the Basis of Data of Sentinel-2, Landsat-8, PlanetScope
}

\author{
Natalya N. Karabkina., Nurlan E. Bekmuhamedov, Olga V. Dolbnya, Aset A. Arystanov,
} Ainur S. Aysarova, Ranida Arystanova, Rekhangul A. Kurbanova, Rashid T. Iskakov

\author{
National Centre for Space Research and Technology, Almaty, Kazakhstan \\ nkarabkina@mail.ru
}

\begin{abstract}
The paper discusses the methodological basis for solving the tasks of space monitoring of grain crops in South Kazakhstan, including the recognition of the sowing mask for winter and early spring grain crops, estimation of the time and area for sowing and harvesting crops, condition and yield of grain crops. The technological scheme for the preparation of operational weekly information provides for the use of a combination of satellite data Sentinel-2, Landsat-8, PlanetScope, depending on the size and accuracy of the determination of crop boundaries. To achieve high reliability of satellite information technology provides for the analysis taking into account the prevailing hydrothermal conditions, route survey data, long-term statistical information on the areas of sowing and yield of grain crops. The results of space monitoring are of interest for various agricultural structures, insurance companies, banking structures, agricultural specialists.
\end{abstract}

Keywords: remote sensing, Sentinel-2, Landsat-8, PlanetScope, grain mask recognition, vegetation indices, condition and yield of grain crops, agrometeorological conditions, agriculture 


\title{
ОПЕРАТИВНОЕ РЕШЕНИЕ ЗАДАЧ КОСМИЧЕСКОГО МОНИТОРИНГА ЗЕРНОВЫХ КУЛЬТУР В ЮЖНОМ КАЗАХСТАНЕ НА ОСНОВЕ ДАННЫХ SENTINEL-2, LANDSAT-8, PLANETSCOPE
}

\author{
Н.Н. Карабкина, Н.Э. Бекмухамедов, О.В. Долбня, А.А. Арыстанов, А.С. Айсарова, \\ Р. Арыстанова, Р.А. Курбанова, Р.Т. Искаков \\ Национальный центр космических исследований и технологий, \\ Алматы, Казахстан \\ nkarabkina@mail.ru
}

В работе рассматриваются методические основы решения задач космического мониторинга зерновых культур в Южном Казахстане, включающие распознавание маски сева озимых и ранних яровых зерновых культур, оценки сроков и площадей сева и уборки посевов, состояния, урожайности зерновых культур. Технологическая схема подготовки оперативной недельной информации предусматривает использование сочетания спутниковых данных Sentinel-2, Landsat-8, PlanetScope в зависимости от размера и точности определения границ посевов. Для достижения высокой достоверности спутниковой информации технологией предусмотрено проведение анализа с учетом сложившихся гидротермических условий, данных маршрутных обследований, многолетней статистической информации по площадям сева и урожайности зерновых культур. Результаты космического мониторинга представляют интерес для различных сельскохозяйственных структур, страховых компаний, банковских структур, специалистов сельского хозяйства.

Ключевые слова: спутниковые данные, Sentinel-2, Landsat - 8, PlanetScope, распознавание маски зерновых культур, вегетационные индексы, состояние и урожайность зерновых культур, агрометеорологические условия, сельское хозяйство

Производство зерновых культур является основной отраслью земледелия в Казахстане. Современные средства дистанционного зондирования Земли (Д33) позволяют получать оперативную пространственную информацию о проведении сельскохозяйственных работ на полях, состоянии и прогнозировании урожайности сельскохозяйственных культур на больших площадях, оценить происходящие изменения в развитии и состоянии посевов в динамике на определенные даты в виде карт-схем, таблиц и графиков на различном административном уровне (поле, хозяйство, район, область).

Землепользование Южного Казахстана включает земледельческие районы Алматинской, Жамбылской, Туркестанской, Кызылординской областей. Здесь возделывается большой набор сельскохозяйственных культур: озимые и ранние яровые зерновые культуры, поздние зерновые культуры (кукуруза, рис), масличные (сафлор, подсолнечник, соевые бобы), бахчевые, овощные, корне- и клубнеплоды, технические культуры (сахарная свекла, хлопчатник), многолетние и однолетние сеяные травы и др. Площадь сева озимых и яровых зерновых культур (согласно статистическим данным), составляет в южных областях Казахстана более 1 млн. га или свыше 40 \% от всех засеваемых площадей. Объектом наших исследований являются посевы зерновых культур, которые представлены озимыми зерновыми (основная культура озимая пшеница) и яровые зерновые (преимущественно яровой ячмень и рис). Посевы возделываются 
преимущественно на полях на равнине и в предгорной зоне в богарных условиях, и на очень небольших площадях в севооборотах в орошаемой зоне.

Космический мониторинг зерновых культур предусматривает подготовку следующих оперативных отчетов в виде карт-схем и таблиц векторного и растрового формата: определение посевных площадей, площадей и сроков сева и уборки сельскохозяйственных культур с недельной детализацией; площадей парования полей; оценка состояния и засоренности зерновых культур; прогноз урожайности озимых и яровых зерновых культур.

Для решения тематических задач по зерновым культурам разработана технология оперативного проведения спутникового мониторинга зерновых культур в Южном Казахстане. Она основана на совместном использовании спутниковой и наземной информации (Рисунок 1). На юге Казахстана посевы расположены на небольших по площади полях (по 50-200 га - в богарной зоне и крайне мелких орошаемых поля от 0,5-3,0 до 4,0-5,0 га - в зоне орошения). Поэтому использование информации одной спутниковой системы является недостаточным условием. Основная часть исходных данных дистанционного зондирования представлена космоснимками Sentinel-2, Landsat-8, с периодичностью от 3 до 8 дней. Спутниковые данные позволяют корректно и оперативно отслеживать недельные итоги посевной и уборочной кампаний в южных областях РК. Для орошаемых территорий с наличием многочисленных мелких полей применяются дополнительно снимки высокого разрешения от источника PlanetScope (3 м). Оценка уборочных площадей зерновых культур за период июль-август проводится по космоснимкам Sentinel-2, в отдельных случаях Landsat - 8, а с сентября дополнительно привлекаются снимки PlanetScope для формирования ежедневных отчетов.

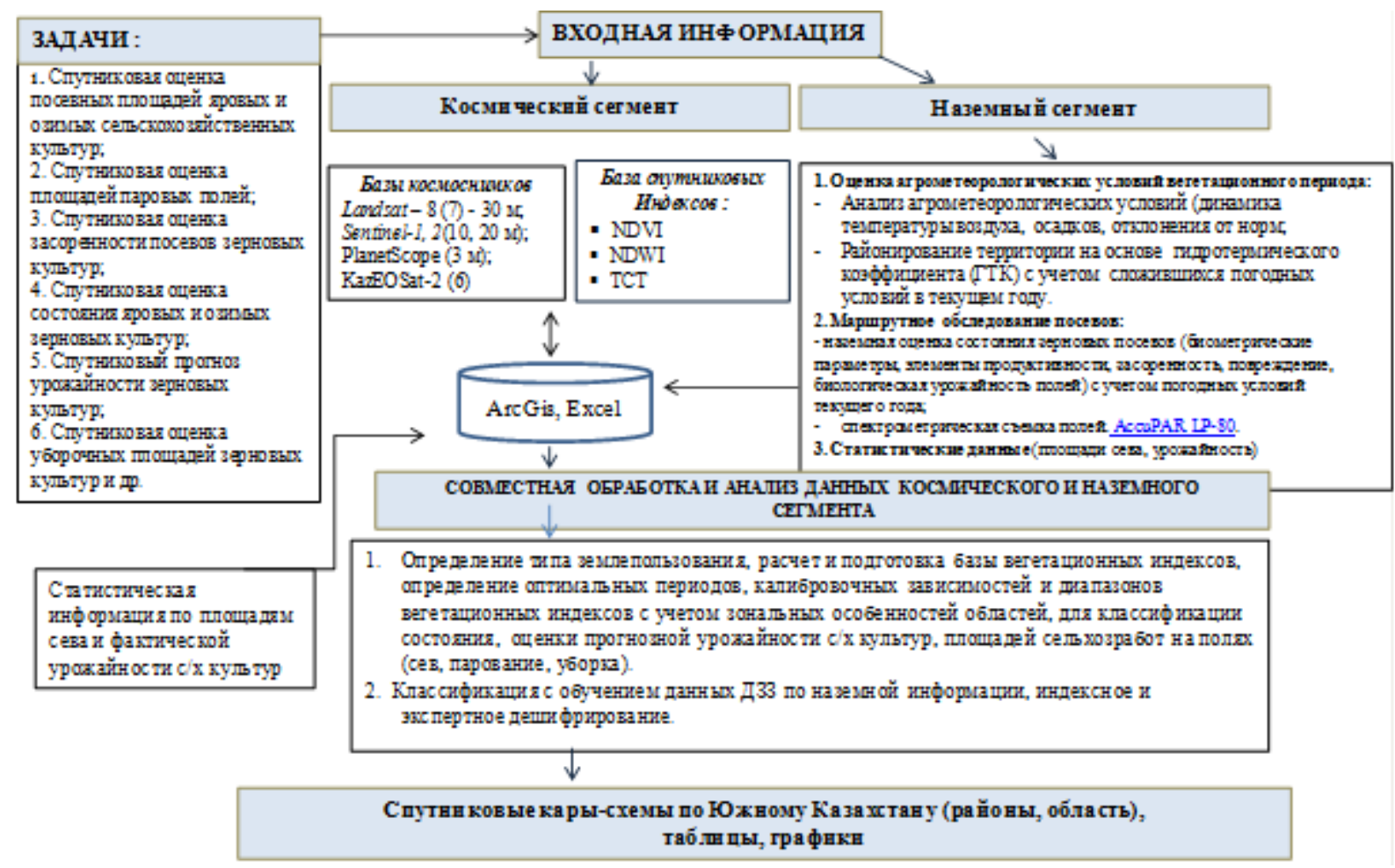

Puc.1. Технологическая схема космического мониторинга зерновых культур в Южном Казахстане

Технология космического мониторинга в условиях каждого года учитывает корректировку маски сева отдельно по озимым и яровым сельскохозяйственным культурам, а в вегетационный период (во время колошения - цветения зерновых культур) выделение маски сева озимых зерновых культур и ранних яровых зерновых.

Дистанционное распознавание маски полей озимых и яровых сельхозкультур основана на учете закономерностей развития возделываемых видов сельскохозяйственных культур на юге Казахстана, сроках проведения полевых работ (сев, парование, уборка), анализе мельчайших различий в спектральных характеристиках засеянных полей, которые выделяются на 
космоснимках при распашке полей осенью и весной. Для озимых посевов оценочным периодом осенью является период с сентября по ноябрь и апрель - июнь, когда заметно наблюдается увеличение биомассы у озимых посевов и значений NDVI. Для яровых зерновых посевов оптимальный период для их распознавания наступает в южных областях Казахстана $c$ мая по июнь.

Методическую основу для распознавания зерновых посевов составляют полевые измерения и наблюдения в сочетании с индексами отношений спектральных яркостей: вегетационные индексы с поправкой на влияние почв и атмосферы (NDVI, классификация на основе преобразования Tasseled Cap, и др.), экспертное дешифрирование на основе различных комбинаций каналов («естественные», «искусственные цвета»). Для зоны предгорных районов для выделения определенных классов объектов также использовалось преобразование Tasseled Cap, которое представляет комбинацию каналов для спутников Sentinel-2 $(2-4,8,11,12)$ и Landsat8 (2-7), и является эффективным методом обработки многоспектральных снимков.[1-2]. В качестве примера, на рисунке 2 приводится пример распознавания маски озимых и яровых зерновых культур.
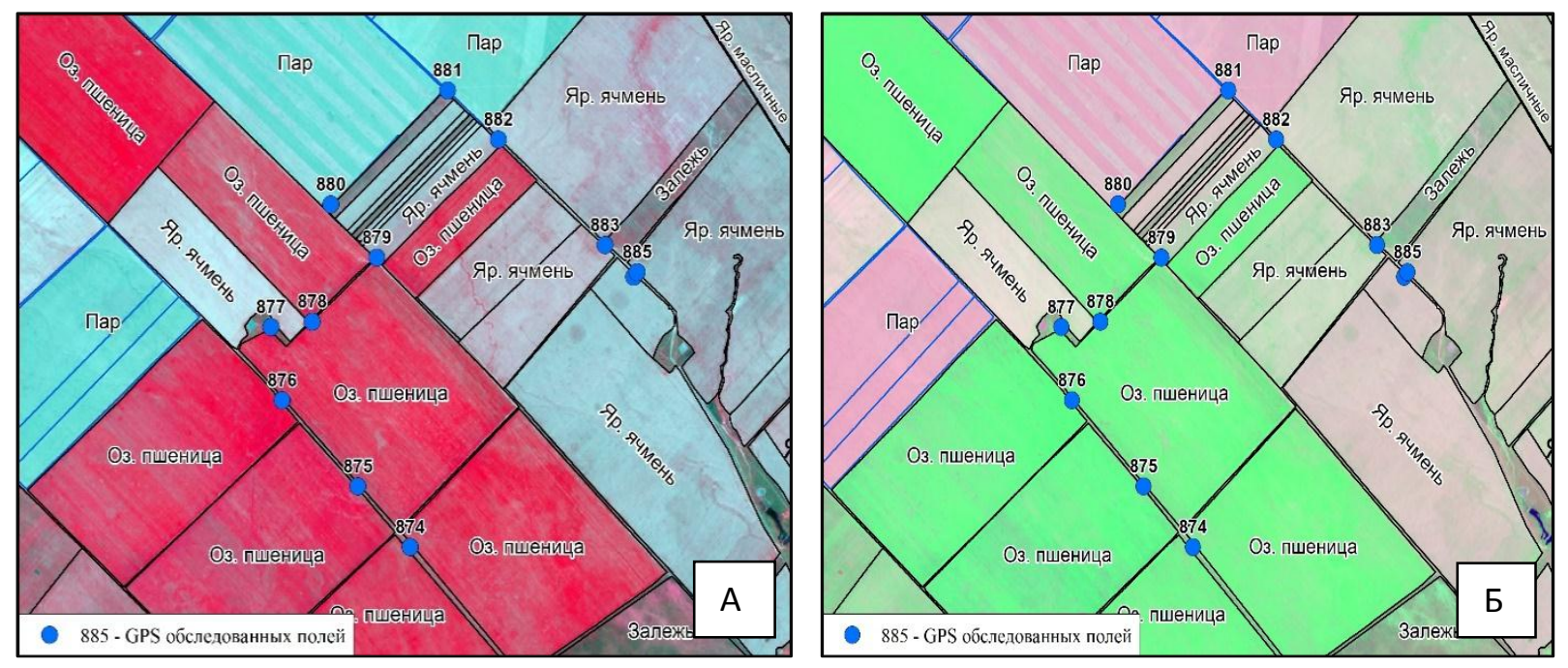

Puc.2. Фрагмент распознавания маски озимых и яровых зерновых культур на снимке Sentinel - 2 за 22.05.2018 г. для полей Турара Рыскулова района Жамбылской области на основе комбинаций каналов RGB: A - «псевдоцвета» (8,4,3); Б - «натуральные цвета» $(12,8,3)$

Для более качественного и детального разделения сельскохозяйственных культур по видовому составу методикой предусмотрен учет условий фенологического развития растений на основе анализа динамики развития посевов по серии снимков, получаемых в течение вегетационного периода и сопоставления спутниковых данных с результатами маршрутного обследования. Полученные окончательные маски озимых зерновых культур и ранних яровых зерновых культур, составляют основу для выполнения последующих тематических задач по растениеводству.

Решение задач мониторинга на основе ДЗ3 учитывает особенности произрастания зерновых культур в отличающихся почвенно-климатических зонах и различных формах рельефа. Для учета особенностей возделывания посевов в 2018 г. территория Южного Казахстана была районирована на однородные зоны увлажнения, с учетом рельефа местности. Определение однородных агрометеорологических условий в 2018 году проводилось на основе расчетных значений гидротермического коэффициента $\quad$. Т. Селянинова (ГТК) за период с апреля по июнь 2018 г.[3]. Для анализа результатов также привлекались данные карты-схемы рельефа местности, выраженные значениями высот над уровнем моря (м). Проведенный анализ агрометеорологических условий 2018 г. позволил районировать территорию Южного Казахстана на влажные, засушливые зоны, в отдельных случаях выделить территории с переходными зонами увлажнения и орошаемым земледелием. В пределах выделенных различных зон увлажнения были разработаны маршруты обследования посевов зерновых культур (Рисунок 3). 

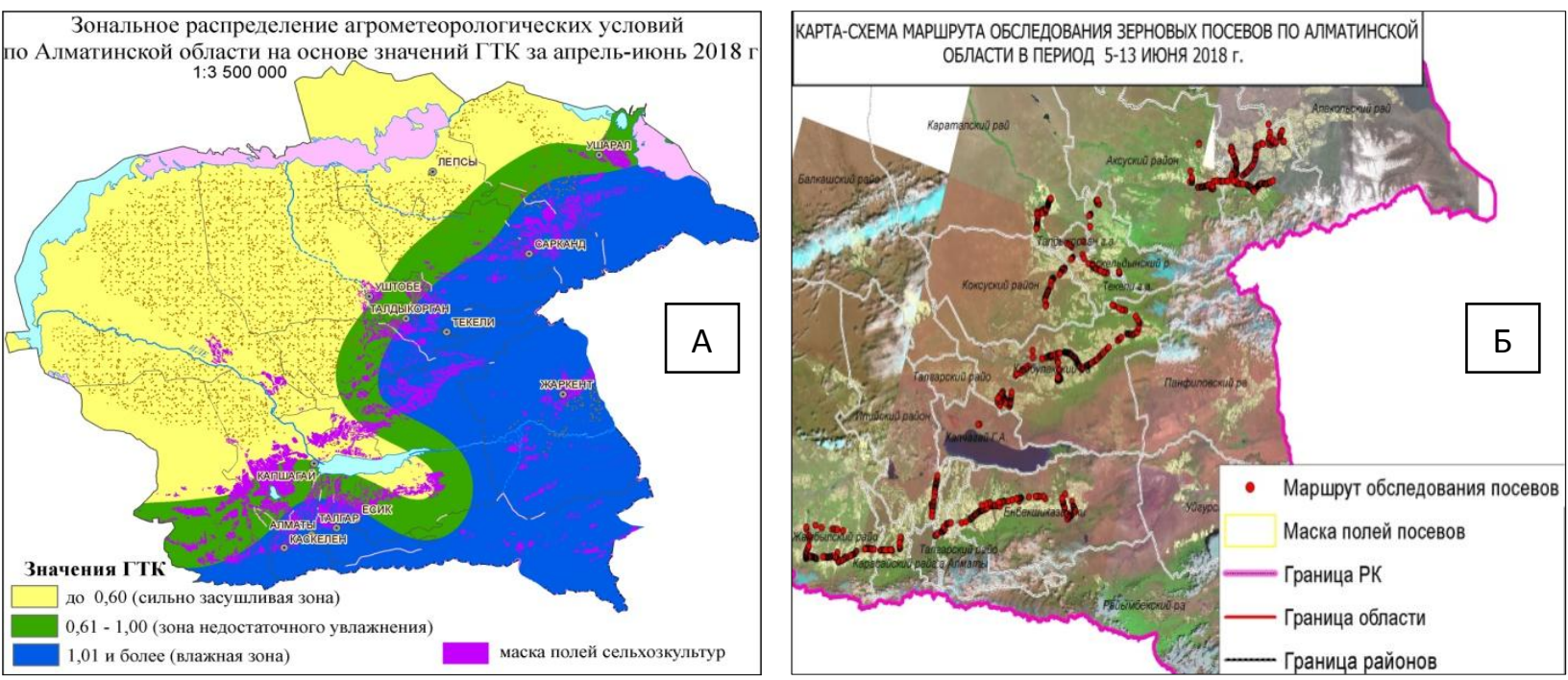

Рис.3. Зональное распределение гидротермических условий для разработки маршрута обследования посевов в 2018г.: А - динамика значений ГТК за апрель - июнь 2018 г.;

Б - карта-схема маршрута обследования по Алматинской области 05-13июня 2018г.

Обследования в Туркестанской, Жамбылской, Алматинской областях были проведены с 25 мая по 14 июня 2018 г. По данным обследований был собран материал с более 2000 полей различных сельскохозяйственных культур, из них по озимой пшенице обследовано более 500 полей, по яровым зерновым - 465 полей. При обследовании определены GPS-координаты полей, фенологическое развитие, элементы продуктивности и структура урожая (высота, густота, продуктивность колоса, биологическая урожайность), степень засоренности, повреждения неблагоприятными погодными условиями или болезнями.

Для решения задач мониторинга по оценке состояния и прогнозированию урожайности зерновых культур разработана и применена технология последовательной обработки спутниковой и наземной информации в 2 этапа. На первом этапе выполняется классификация и картирование состояния посевов зерновых культур по классам (отличное, хорошее, удовлетворительное, плохое) на основе пороговых значений NDVI (максимум за период с мая по июнь) по снимкам Sentinel-2, Landsat-8, верифицированными с наземными данными (рисунок 4). По данным Д3З и наземной информации класс посевов с очень плохим состоянием в погодных условиях 2018 г. отсутствовал. Расчет площадей различного класса состояния зерновых посевов выполняется на уровне районов и в целом по области отдельно для маски озимых зерновых и ранних яровых зерновых культур.

На втором этапе, выполняется расчет прогнозируемой урожайности в зависимости от оцененных площадей различного состояния зерновых по районам, максимальных значений NDVI для полей, а также наземной биологической урожайности для разных классов состояния посевов и зон увлажнения.

Совместный анализ спутниковых и наземных данных с учетом зональных особенностей территории южных областей РК, позволил определить пороговые значения NDVI и оценить состояние посевов по 4 классам состояния (отличное, хорошее, удовлетворительное, плохое). Площади каждого класса состояния посевов на уровне районов и областей были рассчитаны на основе программного продукта ArcGis. 


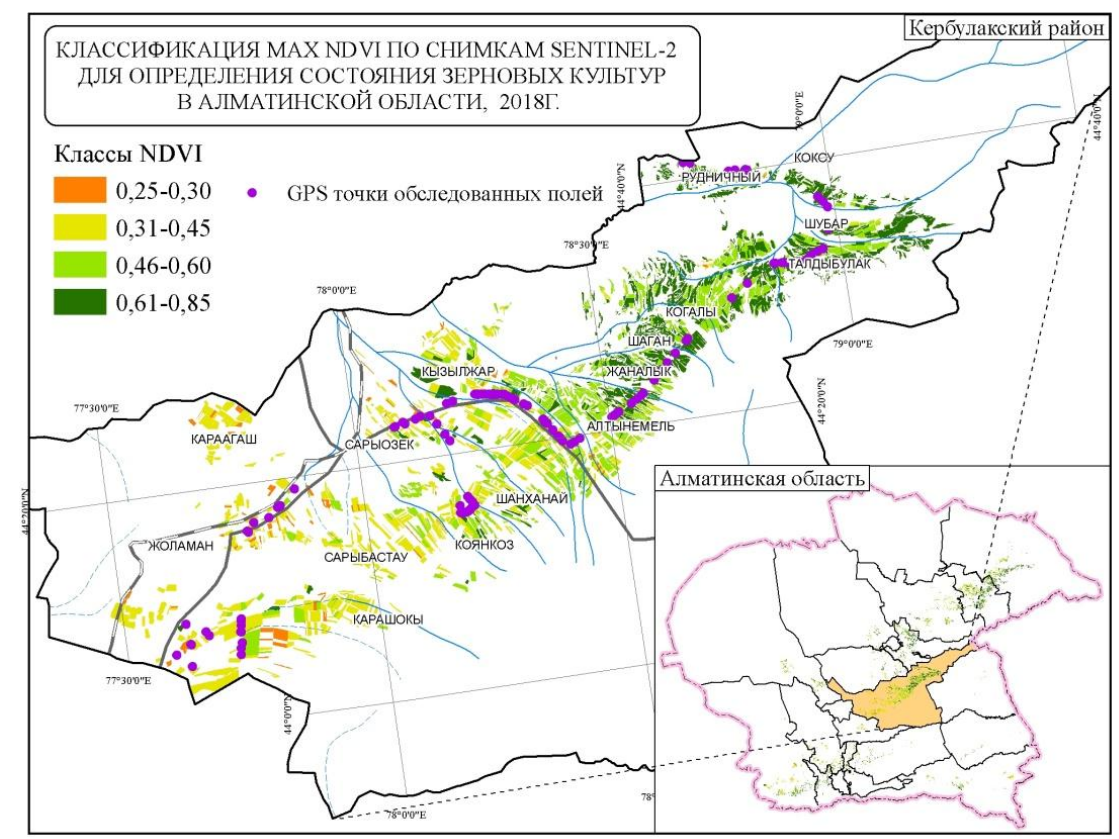

Puc. 4. Фрагмент карты-схемы распределения значений NDVI по снимкам Sentinel-2 на максимум развития зерновых культур в Алматинской области в 2018 году

В качестве методической основы для подготовки спутникового прогноза урожайности зерновых культур в разрезе районов южных областей Казахстана использовались площади классов состояния посевов и данные наземных оценок биологической урожайности для соответствующих классов состояния полей. Для верификации спутниковых данных технологией предусмотрено использование статистической информации по урожайности и площадям сева зерновых культур в разрезе районов южных областей Казахстана за последние 5 лет [4].

По данным космического мониторинга зерновых культур получены спутниковые картысхемы и табличные данные оценки площадей сева, темпов и площадей уборочных работ, парования полей, состояния и прогнозной урожайности зерновых культур по отдельным районам и областям в Южном Казахстане. Проведена верификация результатов. В качестве примеров, на рисунках 5-6 приводятся фрагменты карты-схемы спутниковой оценки состояния и прогнозной урожайности зерновых культур в погодных условиях 2018 г. для отдельных районов Алматинской области.

По результатам космического мониторинга и наземным данным в 2018 г. определено, что на преобладающей территории Южного Казахстана рост, развитие и формирование урожайности зерновых культур проходили при благоприятных агрометеорологических условиях. В связи с этим состояние зерновых культур в Алматинской и Жамбылской областях на 67-73 \% площади оценено как хорошее и отличное, на 26-30 \% - удовлетворительное, и только на 1-3 \% - плохое.

Состояние посевов в Туркестанской области из-за засушливых условий в отдельных равнинных районах оценивается несколько хуже. Здесь у $51 \%$ - состояние хорошее и отличное, у $35 \%$ площади - удовлетворительное и у $14 \%$ площади - плохое. Результаты спутниковой оценки состояния посевов хорошо согласуются с данными наземных обследований и используются в качестве основы для спутникового прогноза урожайности зерновых культур на уровне районов и в среднем по областям.

Прогнозируемые значения урожайности зерновых культур по данным ДЗ3 и наземной информации в Туркестанской области составили - 16-17 ц/га, в Алматинской, Жамбылской областях - свыше 20-22 ц/га, погрешность составляет 5-10 \%. Прогнозные оценки урожайности яровых и озимых зерновых культур в разрезе районов Алматинской области приводятся на рисунке 7. 


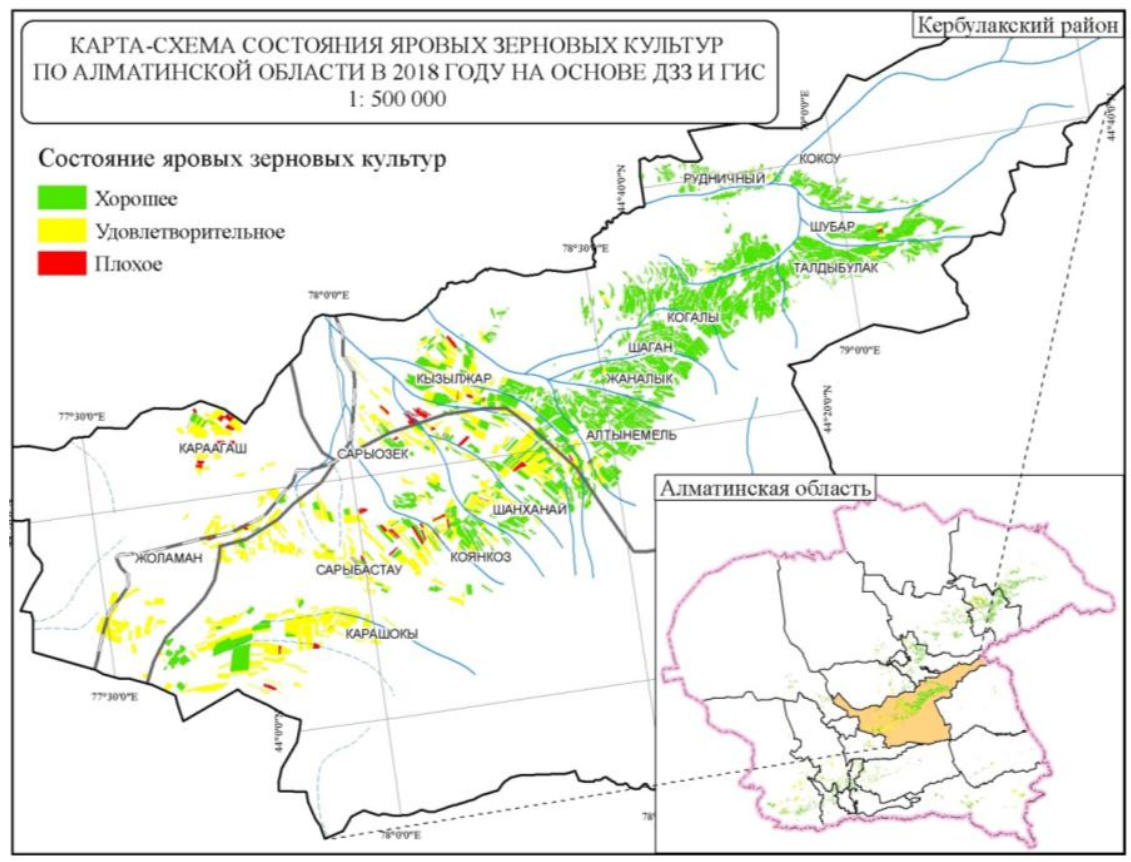

Puc. 5. Фрагмент спутниковой карты-схемы состояния зерновых культур в Кербулакском районе Алматинской области в 2018 г.

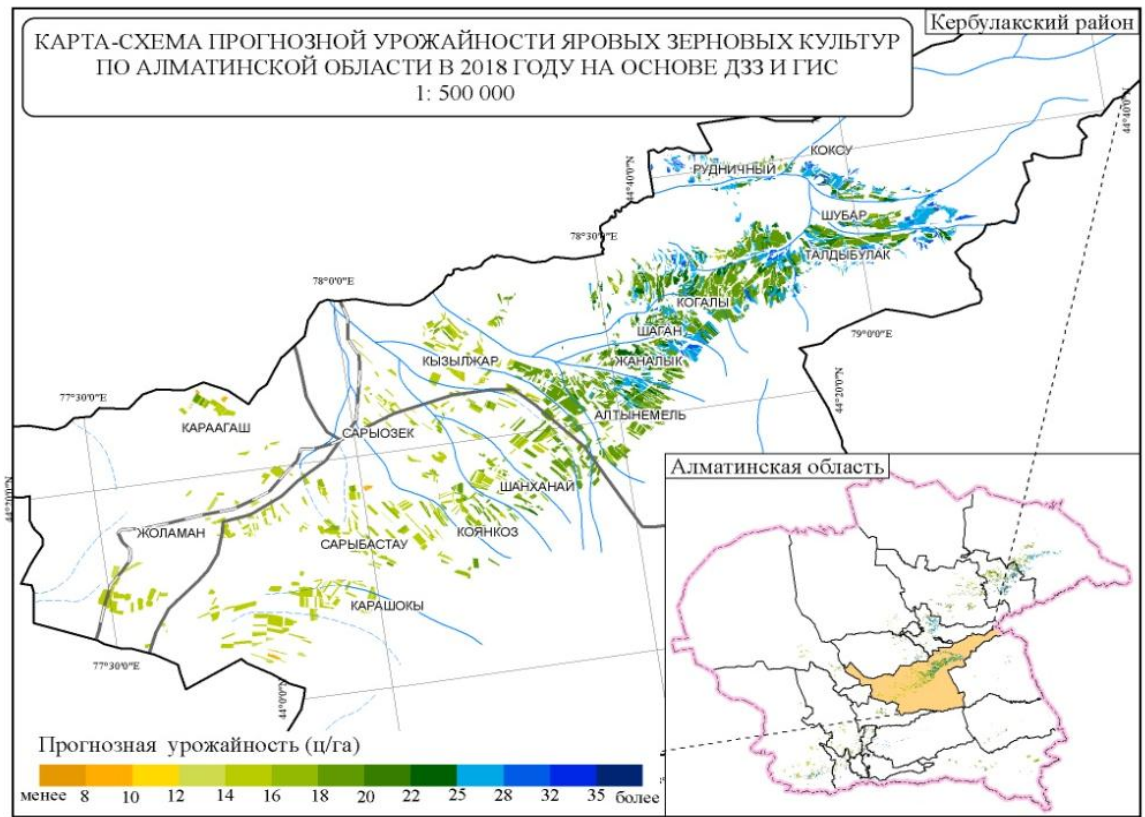

Puc. 6. Фрагмент спутниковой карты-схемы прогнозной урожайности яровых зерновых культур в Кербулакском районе Алматинской области в 2018 г.

По мере созревания посевов к массовой уборке зерновых культур на юге Казахстана приступили в конце июня - начале июля и продолжались в большинстве районов до сентября. К началу октября уборка ранних зерновых культур в 2018 г. была завершена. Определение сроков уборочных работ основано на спектральных и текстурных изменениях на полях в период созревания посевов, которые определяются по двум ближайшим датам на космоснимках Sentinel2, Landsat-8, PlanetScope. Верификация спутниковых оценок проводится с данными маршрутных обследований и статистической информацией. По данным космического мониторинга подготовлены карты-схемы размещения убранных полей по срокам уборки, а также рассчитаны площади уборки зерновых культур по неделям в виде таблиц и графиков в разрезе районов Южного Казахстана (рисунок 8). 

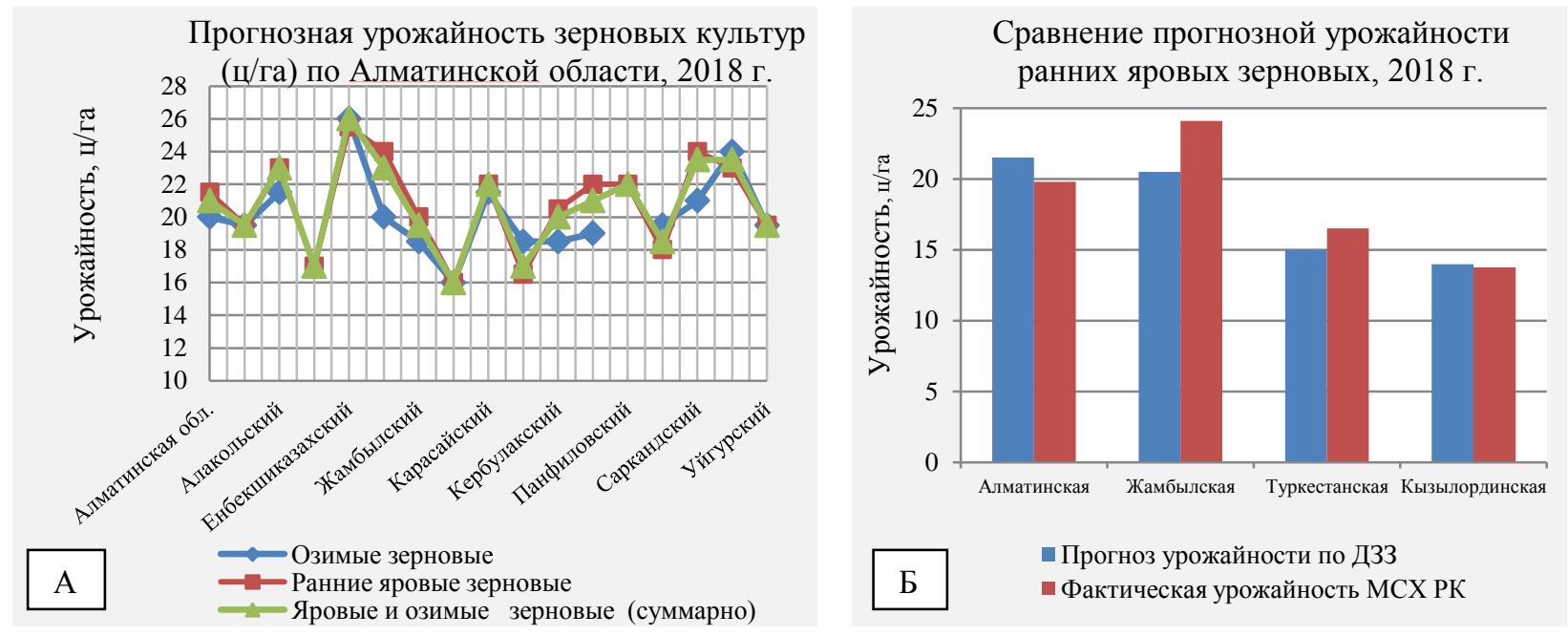

Рис. 7. Прогноз урожайности зерновых культур по районам в 2018 г.:

А - прогноз урожайности по ДЗЗ; Б - сравнение прогнозируемой и фактической урожайности

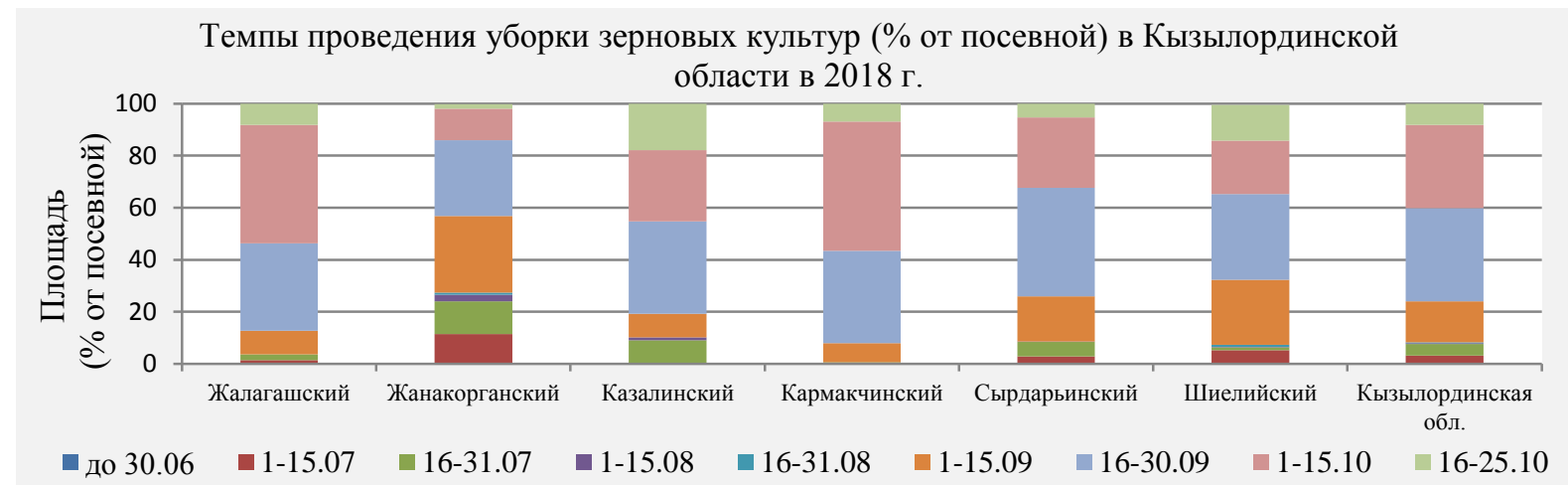

Puc. 8. Темпы проведения уборки озимых, ранних яровых зерновых культур и риса (\% от посевной площади) по районам Кызылординской области в 2018 г.

В результатах спутникового мониторинга крайне заинтересованы сельскохозяйственные государственные организации, страховые компании, банковские структуры, аграрные биржи и корпорации, занимающиеся поставками зерна на внутренний рынок и на экспорт, а также непосредственно сами сельхозпроизводители в хозяйствах.

Финансирование в рамках целевой программы BR05336383 Аэрокосмического комитета Министерства оборонной и аэрокосмической промышленности Республики Казахстан (АКК МОАП РК).

\section{References}

[1] Maxim A. Altyntsev. Accuracy Assessment of Calculated Correlation Coefficients of Tasseled Cap Transformation for Formosat-2 Imagery, Bulletin of the Siberian State University of Geosystems and Technologies,2011, Novosibirsk, pp. 67-73. (In Russian).

[2] Terekhin E. Informational content of spectral vegetation indices for decoding agricultural vegetation, Sovremennye Problemy Distantsionnogo Zondirovaniya Zemli iz Kosmosa, 2012, 9(4), pp. 243-248.

(In Russian).

[3] Scientific and applied reference book on agroclimatic resources of the USSR. Series 2, part 2, issue 18. 1992, Kazakhstan, Almaty. (In Russian).

[4] Sown area and crop yields in 2013-2017 in South Kazakhstan, Zhambyl, Almaty, Kyzylorda regions, Statistics Department of the South Kazakhstan, Zhambyl, Almaty regions of the Ministry of National Economy of the Republic of Kazakhstan. Collection 4 - agriculture: "Statistics of agriculture, forestry, hunting and fisheries», Kazakhstan, Astana. (In Russian). 